The Ukrainian Numismatic Annual, Issue 1.

УДК 930(091) $=161.2$

DOI https://doi.org/10.31470/2616-6275-2017-1-132-142

Зінаїда Зразюк

завідувач сектору нумізматики, фалеристики, медальєрики та боністики, Національний музей історії України

(Київ, Україна)

numismat.nmhu@ukr.net

Zinaida Zraziuk

Chef of sector of numismatics, faleristics, medal and bonistics National museum of history of Ukraine

(Kiev, Ukraine)

numismat.nmhu@ukr.net

\title{
З ІСТОРІЇ НУМІЗМАТИЧНОЇ КОЛЕКЦІЇ ЦЕРКОВНО-АРХЕОЛОГІЧНОГО МУЗЕЮ ПРИ КИЇВСЬКИЙ ДУХОВНІЙ АКАДЕМІЇ
}

\section{FROM THE HISTORY OF THE NUMISMATIC COLLECTION OF THE CHURCH-ARCHAEOLOGICAL MUSEUM AT THE KYIV THEOLOGICAL ACADEMY}

\section{Анотація}

Стаття присвячена нумізматичній колекції Церковно-археологічного музею при Київській духовній академії. Впродовж свого існування (1872-1920рр.) музей зібрав прекрасну колекцію нумізматики, яка була широковідомою далеко за межі Російської імперіі.

31 січня 1873 року указом Св. Синоду був затверджений статут київського Церковно-археологічного товариства та музей при ньому. Першим і єдиним секретарем Товариства став молодий викладач, що пропрацював у академії лише два роки, - Микола Іванович Петров (Рис. 1), який у майбутньому став відомим істориком, заслуженим ординарним професором, академіком.

Поряд 3 церковними старожитностями музей збирав і нумізматичну колекцію. Однією з перших значних пожертв до новоствореного музею була колекція старожитностей і монет, подарована архімандритом Антоніном (А.І. Капустіним). У різні роки до музею дарували монети М.П. Чернєв,і А.Ф. Новицький, М. О. Леопардов та багато інших. Наприкінці XIX століття колекції монет нараховувала близько 17 тисяч одиниць.

Після революції 1917 року діяльність Товариства була майже зупинена. У 1920 р. Київська духовна академія була ліквідована, а всі колекції передали до Лаврського музею культів і побуту. У 30-pp. XX століття нумізматичну колекцію Церковно-археологічного музею передали до історичного музею.

У роки революції, громадянської війни, Першої світової колекція понесла значні втрати - їі кількість скоротилась більше ніж вдвічі і сьогодні предмети, що походять 3 Церковно-археологічного музею є окрасою нумізматичної збірки Національного музею історії України.

У статті прослідковано історію їі створення, згадано людей, які зробили значний вклад у ії створення.

\section{Summary}

The article is devoted to the numismatic collection of the Church Archaeological Museum at the Kyiv Theological Academy. During its existence (1872-1920) the museum collected a beautiful collection of numismatics, which was widely known far beyond the Russian Empire.

On January 31, 1873, the decree of the Holy Synod approved the charter of the Kyiv Church-Archaeological Society and the museum with it. The first and only secretary of the Society 
became a young teacher who worked at the academy for only two years, - Nikolai Ivanovich Petrov (Pic. 1), who in the future became a famous historian, honored by the ordinary professor, academician.

Along with the church's antiquities, the museum collected a numismatic collection. One of the first significant donations to the newly created museum was a collection of antiquities and coins, donated by Archimandrite Antonin (A.I.Kapustinim). In different years, the museum donated coins Mp. Chernev, and AF Novytsky, M.O. Leopardov and many others. At the end of the nineteenth century, the collection of coins amounted to about 17 thousand units.

After the revolution of 1917, the activities of the Society were almost stopped. In 1920 the Kyiv Theological Academy was liquidated, and all collections were transferred to the Lavra Museum of Cults and Life. In the 30's The XX-th century numismatic collection of the Church Archaeological Museum was transferred to the Historical Museum.

During the Revolution, the Civil War, World War II, the collection suffered significant losses - its number has decreased by more than twice, and today items originating from the Church Archaeological Museum are an ornament of the numismatic collection of the National Museum of Ukrainian History.

The article follows the history of its creation, mentioned people who have made a significant contribution to its creation.

Ключові слова - Церковно-археологічний музей, М.І. Петров, нумізматична колекція, Київська духовна академія, Національний музей історії України;

Keywords: Church and Archaeological Museum, M.I Petrov, numismatic collection, Kyiv Theological Academy, National Museum of Histiry of Ukraine;

Нумізматична колекція Національного музею історії України одна 3 найбільших і найстаріших нумізматичних колекції нашої країни. Вона створювалась і накопичувалась впродовж більше, ніж 200 років. У 30 -ті pp. XX ст. три найбільші нумізматичні колекції Києва - мюнц-кабінет Університету Св. Володимира, колекція Церковно-археологічного музею при Київській духовній академії та колекція Художньо-промислового музею були об'єднані. Мета даної розвідки розказати про одну 3 цих широко відомих колекцій - нумізматичну колекцію Церковноархеологічного музею при Київській духовній академії.

Важливим джерелом для дослідження історії Церковно-археологічного музею та його нумізматичної колекції $\epsilon$, перш за все, друковані видання які виходили у часи існування цієї установи. Це «Отчеты Церковно-археологического общества при Киевской духовной академии», які видавались з 1874 року, а з 1901 року вони отримали назву «Отчеты Церковно-исторического и археологического общества при Киевской духовной академии». У звітах міститься інформація про найбільш цікаві надходження до колекції, коротка інформації про реферати прочитані на наукових засіданнях товариства, списки членів Церковно-археологічного товариства.

Велике значення для дослідження колекції нумізматики є спогади єдиного зберігача музею i незмінного секретаря Церковно-археологічного товариства M.I. Петрова, що були опубліковані у часописі «Медієвістика історія церкви науки i культури» ${ }^{1}$ Важливим джерелом для дослідження складу колекції $\epsilon$ «Указатель Церковно-археологического музея при Киевской духовной Академи», складений M.I. Петровим у 1897 році $^{2}$ та його ж опис колекції М.О. Леопардова. ${ }^{3}$

Важлива інформація з історії створення і роботи Церковно-археологічного музею та його колекцій міститься в архівних матеріалах, що зберігаються у

\footnotetext{
${ }^{1}$ Петров Н.И.. Воспоминания старого археолога./Медієвістика історія церкви науки і культури. -вип. I - Київ, 1997.С.93-134.

${ }^{2}$ Петров Н.И. Указатель Церковно-археологического музея при Киевской духовной академии. - К., 1897. - С.171-291.

3 Петров Н.И. Коллекция древних предметов и монет, пожертвованные Церковно-археологическому музею при Киевской духовной академии Почетным членом Церковно-археологического Общества при сей Академии, действительным статским советником Николаем Ивановичем Леопардовым. - К., 1895. - С.45-82.
} 
Центральному державному історичному архіві України у місті Києві ${ }^{1}$, Інституті рукопису Національної бібліотеки України імені В.І. Вернадського ${ }^{2}$, архіві Національного музею історії України. ${ }^{3}$

У 90-ті - 2000-ті роки ряд дослідників звертались до історії Церковноархеологічного товариства та його діяльності, вивчали склад окремих колекції музею при Київській духовній Академії. Історії створення товариства присвячений розділ у монографії С.З. Заремби. ${ }^{4}$ Історія окремих колекцій міститься у працях Л.В. Шаріпової5, І.В. Шульца ${ }^{6}$ тощо. Деякі дослідники у своїх наукових розвідках присвячених Товариству і музею приділяли увагу і нумізматичним пам'яткам, що зберігались у ньому. Інформація про склад і долю нумізматичної колекції містяться у роботах К.К. Крайнього ${ }^{7}$, Г.В. Полюшко ${ }^{8}$, Б.Б. Гарбуза ${ }^{9}$

Не зважаючи на те, що існує достатньо велика джерельна база і ряд дослідників у своїх працях висвітлювали діяльність Церковно-археологічного товариства, його музею та колекцій які він збирав, проте існує велика кількість нових не опублікованих джерел, які висвітлюють історію створення і долю саме нумізматичної колекції - цієї без перебільшення видатної наукової і музейної установи.

У другій половині XIX ст. у Києві з'явився ще один музей - 31 січня 1873 року указом Св. Синоду був затверджений статут київського Церковноархеологічного товариства та музей при ньому. Церковно-археологічне товариство та музей були унікальним явищем у тодішній Російській імперії, адже він став першим музейним закладом, який своїм головним завданням ставив збереження i вивчення церковно-археологічного та історичного матеріалу. Крім археологічних i історичних артефактів, у збірці музею існувала і нумізматична колекція, яка за своїм складом стала широковідомою не тільки у Києві, а й далеко за межами Російської імперії.

Одним з ініціаторів створення товариства і музею був колишній професор Києво-Могилянської академії П.А. Лошкарьов. Готуючись взяти участь у Другому археологічному з’їзді 1871 року як депутат від Київської духовної академії, професор П.А. Лошкарьов та комісія у складі А.Д. Воронова та Ф.А. Терновського склала записку про влаштування церковно-археологічних музеїв. Записка була прочитана на Другому археологічному з'їзді ${ }^{10}$.

Після закінчення з'їзду П.А. Лошкарьов звернувся до академічного правління 3 конкретними пропозиціями щодо утворення церковно-археологічного товариства та музею і підготував проект статуту. Після розгляду і внесення змін статут Церковно-археологічного музею був затверджений указом Св. Синоду від 31. 01.1873 p. $^{11}$ Цей устав діяв до 1881 року.

\footnotetext{
${ }^{1}$ Центральний державний історичний архів України у місті Києві (далі ЦДІА України). - Фонд Церковно-історичного та археологічного товариства. - Ф.1396; Фонд Київської духовної Консисторії. - Ф. 127; Фонд Києво-Печерської лаври. - Ф. 128.

2 Інститут рукопису Національної бібліотеки України імені В.Вернадського (далі ІР НБУВ). - Ф. 160 ; Фонд М.І. Петрова .- Ф. 225.

${ }^{3}$ Архів Національного музею історії України (далі НМІУ) - Ф. Р-1260. - Оп.1., Оп.1 доп.

4 Заремба С.З.Українське пам'яткознавство: історія, теорія, сучасність. - К.,1995. - С.102-117.

${ }^{5}$ Шаріпова А.В. 3 історії рукописного зібрання Церковно-археологічного музею при Київській духовній академії // Рукописна та книжкова спадщина України. - К.,1993. - Вип.1. - С.123-133.

6 Шульц І.В.До історії формування колекції живопису Києво-Печерського заповідника // Мистецька спадщина. Матеріали та дослідження. - К.,1993. - С. 3-15.

${ }^{7}$ Крайній К. Київське Церковно-історичне та археологічне товариство 1872-1920 // Лаврський альманах. - Вип.4. - К., 2001. - C.5-64.

${ }^{8}$ Полюшко Г.В.. Втрачені скарби Лаврського музею. - К., Абрис, 2001. - 174 с.

${ }^{9}$ Гарбуз Б.Б. Нумізматична колекція Національного музею історії України // Вісник НБУ. - № 3 - К. 1996. - С.84-90.

${ }^{10}$ Труды Археологического съезда в Санк-Петербурге в 1871 г. - СПб, 1876. - Вып.1. - С.60.

${ }^{11}$ Петров Н.И.. Воспоминания старого археолога./Медієвістика історія церкви науки і культури. -вип. I - Київ, 1997.C.94.
} 
Першим і єдиним секретарем Товариства став молодий викладач, що пропрацював у академії лише два роки, - Микола Іванович Петров, який у майбутньому став відомим істориком, заслуженим ординарним професором, академіком.

Період 31873 р. по 1881 р. М.I. Петров назвав першим етапом існування Товариства. За першим статутом, перед Товариством постало головне завдання пошук необхідних експонатів та впорядкування новоствореного музею ${ }^{1}$. У статуті було вказано також і три засоби придбання експонатів - купівля, обмін та пожертви. Проте, за браком коштів (адже Товариство існувало на благодійні внески) закупівлі експонатів провадились не досить часто. Обмін експонатів був неприйнятний для існування музею, створеного на благодійні пожертви, а тому цей пункт поповнення музею був зовсім знятий у наступних редакціях статуту. Основним джерелом надходжень музею стали добровільні пожертви.

Однією з перших значних пожертв до новоствореного музею була колекція старожитностей і монет, подарована архімандритом Антоніном (А.І. Капустіним) ${ }^{2}$, який був відомий не лише як священик але й як вчений. Він був членом багатьох російських і закордонних наукових товариств серед яких Російське археологічне товариство, Одеське товариство історії та старожитностей, Афінське археологічне товариство, Київське Церковно-археологічне товариство тощо. ${ }^{3}$ Коло наукових інтересів Антоніна поширювалось не тільки на богословські науки, алей на археологію, археографію, нумізматику, палеографію переважно римського та візантійського часів. ${ }^{4}$

Антонін багато подорожував і під час своїх мандрів зібрав велику колекцію рукописів на грецькій, слов'янській ти інших мовах, старожитностей дохристиянських часів, а також нумізматичну колекцію.

У 1863 році Антонін відсилає у чотири духовні академії Росії (в СанктПетербург, Москву, Київ та Казань) 2050 античних та середньовічних монет ${ }^{5}$. До Церковно-археологічного музею Капустін передав не тільки дуже цінні археологічні матеріали, але й 300 золотих, срібних i мідних монет - давньоєврейських, давньогрецьких, візантійських і східних. ${ }^{6}$ Хранитель Церковно-археологічного музею М.I. Петров дав високу оцінку нумізматичній колекції Антоніна: „...таким чином зібрані їм досить значні колекції монет стародавньої Греції, автономних та колоніальних i, можливо, візантійських, які були визначені самим дарувальником, i зберігаються у Церковно-археологічному музеї, що лише доповнюються більш пізніми надходженнями". ${ }^{7}$

Через брак досвіту роботи 3 нумізматичним матеріалом та спеціалізованої нумізматичної літератури М.I. Петров звертався за допомогою до професорів університету В.Б. Антоновичу та П.О. Терновському. Як пише Петров: "Ці благородні люди допомагали мені, або краще сказати, загальній справі музею i

\footnotetext{
${ }^{1}$ Петров Н.И.. Записка о состоянии Церковно-Археологического музея при Киевской духовной Академии за перове десятилетие их существования (1872-1882 г.).// Чтения в Церковно-археологическом обществе при Киевской духовной Академии. - вып. 1. - Киев, 1883. - С.1-28.

2 Андрій Іванович Капустін народився 1817 р. в с. Батурино Шадринського повіту Пермської губернії в родині священика. У 1845 р. закінчив Київську духовну академію, кілька років працював у ній викладачем німецької та грецької мов, а також богослов'я. У 1845 р. А.І.Капустін приймає чернечий сан з ім'ям Антонін. Більшу частину життя він присвятив служінню руській православній церкві на Сході. 31850 року він - настоятель посольської церкви у Афінах. 31860 року архімандрит Антонін - настоятель посольської церкви у Константинополі, а з 1865 p. i до смерті (пом. 1893 р.) - начальник Руської духовної місії в Єрусалимі.

${ }^{3}$ Гурулева В.В. Архимандрит Антонин как нумизмат.//Нумизматический сборник. - СПб, 1998 -С.235

${ }^{4}$ Филлипов М.В. О научной и литературной деятельности архимандрита Антонина Капустина (в связи с 90 -летием со дня его кончины: 1894-1984) // Богословские труды. - М., 1986 - Т.27. - С. 212-219.

${ }^{5}$ Гурулева В.В. Вказана праця. - С.240.

${ }^{6}$ ЦДІАК України. - Ф.1396. - Оп.1. - Спр 10. - Арк.18.

${ }^{7}$ Петров Н.И.. Воспоминания ... - С.98.
} 
своїми власними трудами. Вони розібрали, по довіднику Сабатьє, та розмістили у вітринах всі візантійські монети із збірки Антоніна Капустіна"

M.I. Петров у своїх згадках про початкові часи існування Церковноархеологічного товариства і про проблеми, які вставали перед його членами, пов'язаними 3 атрибуцією речей, що надходили до музею в тому числі i нумізматичні писав: «...інколи ми мали проблем з такими дрібницями, про які зараз соромно згадати. Якийсь священик приніс на засідання кинутий в церковний гаманець мідний предмет, з напівстертим зображенням на ній Богородиці у сяйві. Ми довго возилися 3 цією річчю и насамкінець визначили іiі, як медальйон 3 зображенням Богородиці; між тим, виявилось, що то була сама звичайна австроугорська монета Марії-Терезії з зображенням Богородиці, як святої Покровительки Угорщини» ${ }^{2}$.

На першому етапі існування нумізматичної колекції Товариства, М.І. Петров досить часто звертався по допомогу до фахівців з нумізматики з інших установ та міст. Для визначення монет 3 колекції досить часто долучали фахівців. Для визначення східних та давньоєврейських монет були запрошені члени Товариства професор Петербурзького університету M.I. Веселовський та професор Київської академії А.А. Олесницький ${ }^{3}$. А.Ф. Новицький допомагав М.І. Петрову переглянути 35 пудів мідних монет, що вийшли з обігу в Києво-Печерській лаврі, Микільському та Братському монастирях. Члени товариства М.П. Чернєв i А.Ф. Новицький займались визначенням монет і впорядкуванням колекції. М.П. Чернєв склав навіть короткий опис монет західноєвропейських, слов'янських, польських, російських та східних ${ }^{4} .3$ часом М.І. Петров набуває досвіду в нумізматиці і в наступні роки до нього досить часто звертаються з проханням про атрибуцію монет не лише з Києва, а й $з$ інших міст Росії.

У 90-pp. XIX ст. до музею надійшла найбільша за кількістю колекція від дійсного статського радника у відставці Миколи Олександровича Леопардова. Вихованець Вологодської духовної семінарії, він більшу частину життя провів у Кронштадті, на службі у морському відомстві. Заробивши великі гроші на підряді 3 будівництва Кронштадтського театру, він після виходу у відставку переїхав до Києва. Тут М.О. Леопардов незабаром прославився як дилетант-нумізмат, збираючи спочатку лише російські, а згодом і всі інші монети, а також побутові та церковні старожитності. Як відзначав М.I. Петров, «він сам особисто не робив ніяких розшуків i розкопок, довірливо приймаючи всі пропозиції археологів і торгівців старожитностями, а тому нерідко припускався хибних визначень предметів старовини» ${ }^{5}$. Фахівці Церковно-археологічного товариства, почесним членом якого був М.О. Леопардов, суттєво допомагали йому у визначенні давніх пам'яток колекції.

Ця колекція передавалась у музей у три прийоми: самим дарувальником у березні 1894 р., у другий раз - у січні 1895 р. і в третій раз - спадкоємцями покійного - у листопаді 1895 р.6. Склад першої подарованої музею колекції був випущений окремим виданням ${ }^{7}$. Вся колекція була оцінена жертвувателем та його спадкоємцями в 42745 руб.50 коп. сріблом (у цю суму крім нумізматики включено і інші подаровані музею старожитності). Для експонування колекції Леопардова у

\footnotetext{
${ }^{1}$ Петров Н.И.. Воспоминания ... - С.114

2 Петров Н.И.. Воспоминания ...- С. 107

${ }^{3}$ Отчет Церковно-археологического общества про Киевской духовной академии за 1884 год // ТКДА. - 1885. - Т.1. C. $413-439$

${ }^{4}$ Отчет Церковно-археологического общества про Киевской духовной академии за 1885 год // ТКДА. - 1886. - Т.1. С.286-288

${ }^{5}$ Петров Н.И.. Воспоминания.... - С. 129

${ }^{6}$ Петров Н.И. Указатель Церковно-археологического музея при Киевской духовной академии. - К., 1897. - С.238.

7 Петров Н.И. Коллекция древних предметов и монет, пожертвованные Церковно-археологическому музею при Киевской духовной академии....Николаем Ивановичем Леопардовым. - К.,1895.
} 
музеї була виділена частина залу, а монети експонувались в окремих вітринах, на яких зазначалась інформація про те, ким вони були подаровані.

Крім значних за обсягом колекцій, до музею надходили і невеликі пожертви від членів Товариства, почесних відвідувачів і пересічних любителів давнини. Переглядаючи річні звіти Товариства, можна простежити, як поповнювалась колекція, хто дарував для неї речі.

Після створення музею $\mathrm{i}$ надходження до нього перших експонатів розпочалось створення експозиції, в якій чільне місце посіла і нумізматична колекція, що розмістилася у галереї. 31879 р. музей було відкрито для широкого загалу. За статутом, музей працював по неділях, а в разі необхідності - кожного дня. За «Указателем...» 1895 р., в експозиції музею було виставлено 9598 монет давньогрецьких, римських, візантійських, давньоруських, західноєвропейських та ін. Крім того, в окремих вітринах, за бажанням жертвувателя, в експозиції виставлялась і нумізматична колекція Леопардова, яка нараховувала 7238 одиниць ${ }^{1}$.

Колекція з року в рік поповнювалась, проте і мала великі втрати. Найбільші проблеми музею на той час були пов'язані 3 експонуванням монет та їх збереженням. У музеї сталося декілька крадіжок. Одна з найбільших - у ніч з 5 на 6 грудня 1886 року. У музеї було викрадено 42 золотих, 333 срібних і 8 мідних монет. M.I. Петров після попереднього огляду визначив вартість вкраденого в археологічному відношенні в 2000 рублів ${ }^{2}$. Поліція знайшла злочинця, проте до музею вдалось повернути лише 31 монету і зливок срібла, який був зроблений зловмисником з викрадених монет ${ }^{3}$.

31890 p. Товариство найняло для охорони музею спеціального наглядача, але, нажаль, саме наглядач став викрадачем монет. 9 липня 1898 р. музейний служитель, дібрав ключі до вітрини і викрав звідти три монети - півімперіал та платинову монету імператора Миколи I і півімперіал Олександра III. Одну з монет він одразу ж загубив на вулиці, іншу обміняв у бакалії на горілку, а найціннішу - платинову вартістю до 50 крб. - продав ${ }^{4}$. Розшукати платинову монету, яка потрапила до торговця старожитностями, не вдалось.

На початку 1911 р. у музеї сталася значна крадіжка. Згідно $з$ заявою до поліції, написаною М.І. Петровим 29 березня, у лютому-березні 1911 р. злодії, перевдягнуті, очевидно, у форму вихованців навчальних установ, скориставшись товкотнечею, відімкнули 5 вітрин колекції Леопардова. Було викрадено 42 золоті і 46 срібних монет часів Єлизавети Петрівни, Катерини II, Олександра II та Олександра III, загальною номінальною вартістю понад 300 крб. 5 . Злодіїв поліція не знайшла.

Щодо науково-теоретичної діяльності Товариства, то на початку існування, за першим статутом Товариства, така форма діяльності не передбачалась, проте самі члени Товариства неодноразово готували доповіді. 31876 року на засіданнях Товариства встановилась традиція виступати 3 науковими повідомленнями. Основною тематикою цих повідомлень була церковна археологія. Проте серед наукових повідомлень зустрічаються і такі, що були присвячені нумізматичним пам'яткам. Серед них слід відмітити статті М.І. Петрова про бронзову медаль, знайдену у 1885 p. в м. Корсунь ${ }^{6}$, про найдавніші зображення Володимира ${ }^{1}$ та про археологічну знахідку на хорах Успенського собору ${ }^{2}$ тощо.

\footnotetext{
${ }^{1}$ Петров Н.И.. Указатель... - С. 171-197, 281-291.

${ }^{2}$ ЦДІА України. - Ф.1396. - Оп. 1. - Спр. 35. - Арк. 1-2.

${ }^{3}$ Там само. - Арк. 4.

${ }^{4}$ ЦДІА України. - Ф.1396. - Оп. 1. - Спр.68. - Арк. 10-а.

${ }^{5}$ ЦДІА України. - Ф.1396. - Оп. 1.- Спр. 100. - Арк. 1-2.

${ }^{6}$ Петров Н.И. О бронзовой медали с греческой надписью, найденной в 1885 г. в м. Корсуни, Киевской губернии // ТКДА. -1887 . - № 2. - С.298-312.
} 
На останній статті необхідно зупинитися додатково, оскільки це видатна знахідка. Під час ремонту хорів Успенського собору 26 листопада 1898 р. робітники знайшли величезний скарб. За бажанням Духовного собору лаври, Церковноархеологічне товариство на екстреному засіданні 2 грудня 1898 р. призначило особливу комісію 3 своїх членів: професорів П.А. Лашкарева, М.I. Петрова, В.З. Завітневича та чиновника генерал-губернаторської канцелярії О.Ф. Новицького для наукового визначення знахідки. Комісія встановила, що знахідка складалась 3 6184 монет і медалей з золота та 9895 монет і медалей срібних. Серед знайдених монет і медалей - велика кількість унікальних пам'яток, які до цієї знахідки не були відомі науці. У лаврський типографії вийшла книжка, де опубліковано повний склад скарбу ${ }^{3}$. Серед багатьох бажаючих Лавра надала перевагу Ермітажу, який заплатив за скарб досить символічну суму 60 тис. крб. За існуючою тоді традицією, скарб не зберігали у повному обсязі, а лише відбирали з нього відсутні у колекції різновиди монет. Зберігач нумізматичної колекції Ермітажу О.К. Марков відібрав необхідні монети, а потім звернувся до Лаври з пропозицією, за якою вона може повернути другу частину монет собі, заплативши за неї кошти згідно оцінки. Проте Лавра відмовилась 3 посиланням на те, що витратила вже всі кошти, отримані від Ермітажу. Залишки скарбу були розпродані з аукціонів ${ }^{4}$.

Весь час існування Товариство та музей залежали переважно від добровільних пожертв і майже не отримували матеріальної підтримки від Духовної академії. У перший період існування Товариства благодійні внески допомагали його існуванню, проте наприкінці XIX ст., коли у різних єпархіях почали виникати подібні установи, кількість пожертв значно скоротилась, та й музейні площі були замалими для зберігання і експонування величезних колекцій.

Між тим, розпочалась Перша світова війна. Над Києвом нависла реальна загроза захоплення німцями, тому було прийняте рішення про евакуацію музею. У 1915 р. все майно Церковно-археологічного музею було запаковане у 100 ящиків, 15 3 яких були невідкладно відправлені до Казанської духовної академії. У 1916 р. ці ящики були повернуті до Києва і поряд 3 іншими 85 продовжували лежати нерозпакованими у музеї5.

Лише одна людина переймалась долею Товариства і його музею. Це був перший і єдиний iї зберігач M.I. Петров, який віддав музею 47 років життя. Він завершує свої спогади словами: «...Що буде далі з нашим Церковно-археологічним Музеєм, - це тільки одному богу відомо. Одне тільки бажано, щоб наш Музей з його світовими цінностями не приєднувався штучно до якогось вже існуючого вченого або навіть учбового закладу, а мав би самостійне значення і слугував би об'єктом вчених занять й досліджень різних вчених-спеціалістів та художників» ${ }^{6}$.

Після революції 1917 року діяльність Товариства була майже зупинена. Проте київські члени Товариства і далі виконували представницькі функції від його імені. Зокрема, представники Церковно-історичного та археологічного товариства брали участь в урочистому відкритті Археологічного інституту 21 жовтня 1918 р. ${ }^{7}$ та восени 1919 р., за часів денікінської окупації, два члени товариства були запрошені

\footnotetext{
${ }^{1}$ Петров Н.И. древнейших изображениях святого равноапостольного князя Владимира // ТКДА. - 1887. - № 5. - С.6479.

${ }^{2}$ Петров Н.И. Археологическая находка на хорах великой церкви Киево-Печерской лавры // ТКДА. -1899. -№ 6. C.176-195.

${ }^{3}$ Список старинных золотых и серебряных монет и медалей, принадлежащих Киево-Печерской лавре - К., 1898. Типография Киево-Печерской лавры.

${ }^{4}$ ЦДІА України. -Ф.128. - Оп.1. - Спр.2990.

${ }^{5}$ Петров Н.И.. Воспоминания... - С.134.

${ }^{6}$ Там само. - С.134.

${ }^{7}$ Крайній К. Київське Церковно-історичне та археологічне товариство 1872-1920//Лаврський альманах. - Вип.4. - К., 2001. - C.28.
} 
до праці в Комітет охорони пам'яток історії, що діяв при університеті Св. Володимира під головуванням професора М.В. Довнар-Запольського ${ }^{1}$.

Водночас з'явились ідеї відновити роботу Церковно-археологічного музею, але вже на території Києво-Печерської лаври. Це була ініціатива виконуючого обов'язки намісника Києво-Печерської лаври архімандрита Климента ${ }^{2}$. Зрештою, побажання отця Климента, хоча і в дещо зміненому вигляді, були втілені у життя на початку 20-х років, коли на території Києво-Печерської лаври було створено музей культів і побуту. Сюди ж потрапили колекції Церковно-археологічного музею³.

У 1920 р. Київська духовна академія була ліквідована. Після ліквідації вся колекція академічного музею, в тому числі нумізматична, продовжувала знаходитись протягом декількох років у приміщенні колишнього музею. Після евакуації 1915 року колекція не була розпакована і продовжувала зберігатися у ящиках. Хтось 3 місцевих жителів повідомив Губполітпросвіт про те, що майно музею, мовляв, систематично розкрадається, причому саме систематично, тому що біля одного 3 ящиків було знайдено розкритий каталог музею, за яким 3 ящика відбирались предмети. Тоді прийняли рішення про переміщення колекції до Лаври (1926 р. - Всеукраїнське музейне містечко) і розпочали роботу з перевірки музейної колекції, наведенню порядку у майні. Відтак було встановлено, що колекція понесла великі втрати. Тільки золотих монет комісія не дорахувала 300 одиниць ${ }^{4}$

До роботи з перевірки колекції були долучені, крім співробітників музею, кілька студентів Київського археологічного інституту. Під час розбору нумізматичної колекції дехто з них був запідозрений у крадіжці, а один майже спійманий на місці злочину 5 .

На посаду завідуючого нумізматичною колекцією було запрошено професора В.Г. Ляскоронського - історика за спеціальністю. Він мав звірити колекцію, створити нові інвентарі та скласти список речей, що були вкрадені. За час його завідування нумізматичною збіркою (до 1927 р.) вона продовжувала поповнюватись. Було придбано декілька античних монет, частину колекції В.Б. Антоновича близько 800 од. західноєвропейських монет, скарб срібних російських копійок 3 с. Лобутни (700 од.) та переданий з історичного музею «Китаєвський скарб» ${ }^{6}$.

У 1927 році на допомогу професору В.Г. Ляскоронському з Чернігівського державного музею було переведено В.А. Шугаєвського. Після смерті Ляскоронського зберігачем нумізматичної колекції стає В.А. Шугаєвський. У зв’язку 3 тим, що, на думку В.А. Шугаєвського, опис музейної колекції був зроблений дуже непрофесійно, для написання нового каталогу-інвентарю колекції, було створено комісію, що складалася з голови комісії академіка О.П. Новицького, одного з членів вченої ради Музейного містечка (за чергою), зберігача нумізматичної колекції В.А. Шугаєвського та незалежного експерта, відомого київського нумізмата (особливо він знався на античній нумізматиці) М.Г. Захарьєвич-Захарьєвського, який, до слова, був дійсним членом Церковно-історичного i археологічного товариства з 1902 р., а до обрання його членом Товариства неодноразово дарував музею монети і старожитності.

Роботу розпочали наприкінці грудня 1928 р. і завершили через два роки безперервної кропіткої праці. За цей час було визначено та ідентифіковано за авторитетними нумізматичними каталогами 9,5 тисяч монет ${ }^{7}$. Комісія виділяла

\footnotetext{
${ }^{1}$ Неструля О.. Доля церковної старовини в Україні 1917-1941 рр. - К., 1995. - Ч.1. - С.84.

${ }^{2}$ Крайній К.. Вказана праця. - С.29.

${ }^{3}$ Невстрюля О. Вказана праця. - С.114.

${ }^{4}$ Гарбуз Б.Б.. Нумізматична колекція Національного музею історії України // Вісник НБУ. - № 3 - К. $1996 .-$ С.89.

${ }^{5}$ Архів НМІУ. - Ф № Р-1260. -Оп. № 1. - доп, од.зб. №10.- Арк.120.

${ }^{6}$ Там само - Арк. 120а.

7 За «Указателем...», в 1895 р. у експозиції музею було розміщено 9598 монет, медалей та печаток. У колекції Леопардова було виставлено 7238 од. Отже за цими даними кількість монет у колекції складала 16836 од. Ці дані
} 
фальшовані, дублети та стерті монети, для яких складались окремі описи. Iз загальної кількості було виділено 5 тис. колекційних монет. Особливий інвентар було створено для золотих та платинових монет, у якому зроблено докладний опис монет та їх естампаже ${ }^{1}$. Порівняння цієї інвентарної книги з сучасною колекцією музею дала дуже невтішні результати, - жодна з монет та медалей, описаних в цьому інвентарі, не збереглась.

Робота комісії була призупинена у зв'язку з арештом М.Г. ЗахаревичЗахар'євського у грудні 1930 р. В.А. Шугаєвський звернувся з проханням до дирекції Музейного містечка про введення до складу комісії іншого експерта-нумізмата. Такий фахівець був знайдений у Ніжині; ним був у минулому співробітник Ермітажу

Ілюстрації

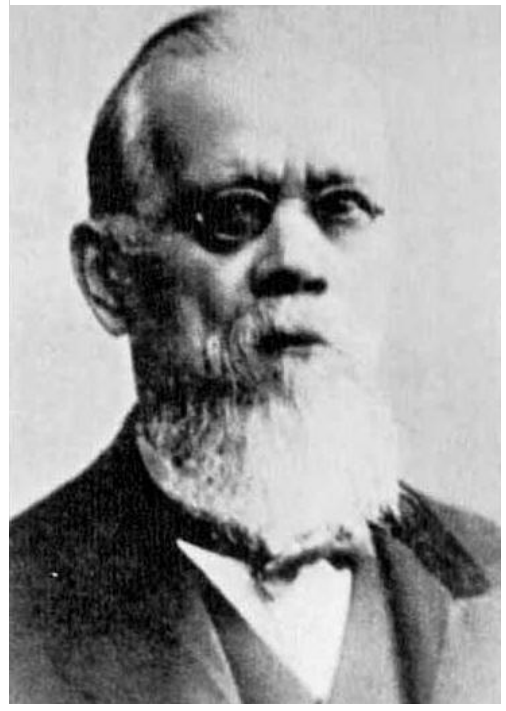

Рис. 1. Микола Іванович Петров (1840-1921).

В.Р. Фохт. Після декількох місяців бюрократичних зволікань Фохта не було введено до комісії. Взимку 1934-1935 pp. адміністрація Музейного містечка вимагає від В.А. Шугаєвського прийняти всю нумізматичну колекцію до історичного музею та перемістити ії до іншого приміщення. Впродовж 1935 р. нумізматичну колекцію Церковно-археологічного музею було передано до історичного музею. 3 цього часу починається нове життя широковідомої нумізматичної збірки Києва у складі колекцій історичного музею.

У роки Другої світової війни була втрачена фондова документація на предмети нумізматики, в результаті чого всі три колекції - мюнц-кабінету університету Св. Володимира, Церковно-археологічного музею та Центрального історичного музею були перемішані між собою. У зв'язку з цим, співробітники відділу нумізматики вважають, що їх головне завдання полягає у необхідності вивчення складу колекції, а також у встановлені іiі історії в цілому та по кожній монеті окремо.

\section{Джерела}

1. Інститут рукопису Національної бібліотеки України імені В.І. Вернадського. - Ф. 160.

2. Інститут рукопису Національної бібліотеки України імені В.І. Вернадського. - Ф. 225 (Фонд М.І. Петрова ).

3. ЦДІА України. - Ф. 1396 (Фонд Церковно-історичного та археологічного товариства). Оп. 1. - Спр. 10. - Арк. 18.

4. ЦДІА України. - Ф. 1396 (Фонд Церковно-історичного та археологічного товариства). Оп. 1. - Спр. 35. - Арк. 1-2.

5. ЦДІА України. - Ф. 1396 (Фонд Церковно-історичного та археологічного товариства). Оп. 1. - Спр. 68. - Арк. 10-а.

6. ЦДІА України. - Ф. 1396 (Фонд Церковно-історичного та археологічного товариства). Оп. 1. - Спр. 100. - Арк. 1-2.

7. ЦДІА України. - Ф. 128 (Фонд Києво-Печерської лаври). - Оп. 1. - Спр. 2990.

8. Архів НМІУ. - Ф. 1260 (Історія НМІУ в документах і матеріалах). - Оп. № 1. - доп, од.зб. № 10. - Арк. 120.

9. Архів НМІУ. - Ф. 1260 (Історія НМІУ в документах і матеріалах). - Оп. 1. - Сп., 34а.

вражають і потребують уточнення і додаткової документації та аргументації. Проте, якщо брати до уваги саме ці не уточнені дані, кількість монет на час звірки В.А. Шугаєвського скоротилась майже вдвічі (без урахування крадіжок, нових надходжень до музею у 1895-1915 рр., надходжень до колекції вже після ії переїзду до Лаври).

${ }^{1}$ Архів НМІУ. -Ф.1260. -Оп.1. - Сп., 34а. 


\section{Література}

1. Гарбуз Б.Б. Нумізматична колекція Національного музею історії України / Борис Гарбуз // Вісник НБУ. - № 3 - К. 1996. - С. 84-90.

2. Гурулева В.В. Архимандрит Антонин как нумизмат./ Вера Гурулева // Нумизматический сборник. - СПб, 1998 - С. 235.

3. Заремба С.З. Українське пам'яткознавство: історія, теорія, сучасність / Сергій Захарович Заремба // Центр пам'яткознавства НАН України, Українське товариство охорони пам'яток історії та культури. - Київ : Логос, 1995. - С. 102-117. - 447 с.

4. Крайній К. Київське Церковно-історичне та археологічне товариство 1872-1920 / К. Крайній // Лаврський альманах. - Вип. 4. - К., 2001. - С. 5-64.

5. Нестуля О. О. Доля церковної старовини в Україні. 1917-1941 pp. Ч. 1 : 1917 р. - середина 20-х років: Монографія / О. О. Нестуля. - Київ : Ін-т історії України НАНУ, 1995 - 278 с.

6. Петров Н. И. Воспоминания старого археолога / Н. И. Петров // Просемінарій: Медієвістика. Історія Церкви, науки та культури. - 1997. - Вип. 1. - С. 93-134.

7. Петров Н.И. Археологическая находка на хорах великой церкви Киево-Печерской лавры / Н.И. Петров // ТКДА. - 1899. -№ 6. - С.176-195.

8. Петров Н.И. Древнейших изображениях святого равноапостольного князя Владимира / Петров Н.И. // ТКДА. - 1887. - № 5. - С. 64-79.

9. Петров Н.И. Коллекция древних предметов и монет, пожертвованные Церковноархеологическому музею при Киевской духовной академии Почетным членом Церковноархеологического Общества при сей Академии, действительным статским советником Николаем Ивановичем Леопардовым / Н.И. Петров. - К., 1895. - С. 45-82.

10.Петров Н.И. О бронзовой медали с греческой надписью, найденной в 1885 г. в м. Корсуни, Киевской губернии / Н.И. Петров // ТКДА. -1887. - № 2. - С. 298-312.

11.Петров Н.И. Указатель Церковно-археологического музея при Киевской духовной академии / Н.И. Петров. - К., 1897. - С. 171-291.

12.Полюшко Г.В. Втрачені скарби Лаврського музею / Г.В. Полюшко. - К., Абрис, 2001. $174 \mathrm{c}$.

13.Список старинных золотых и серебряных монет и медалей, принадлежащих КиевоПечерской лавре // Составлен А.К. Марковым - К., 1898. - Типография Киево-Печерской лавры.

14.Труды II Археологического съезда в Санкт - Петребурге. [Санкт-Петербург]: тип. Имп. Акад. наук, [1876], - Вып. 1.

15.Филлипов М.В. О научной и литературной деятельности архимандрита Антонина Капустина (в связи с 90-летием со дня его кончины: 1894-1984)/ М.В.Филлипов // Богословские труды. - М., 1986 - Т. 27. - С. 212-219.

16.Шаріпова Л. В. 3 історії рукописного зібрання Церковно-археологічного музею при Київській духовній академії / Л.В. Шаріпова // Рукописна та книжкова спадщина України. - Київ, 1993. - Вип. 1. - С. 123-133.

17.Шульц І.В. До історії формування колекції живопису Києво-Печерського заповідника / I.В. Шульц // Мистецька спадщина. Матеріали та дослідження. - К.,1993. - С. 3-15.

\section{References}

1. Fillipov, M. V. (1986) O nauchnoj i literaturnoj dejatel'nosti arhimandrita Antonina Kapustina (v svjazi s 90-letiem so dnja ego konchiny: 1894-1984) [On the scientific and literary activities of Archimandrite Antonin Kapustin (in connection with the 90th anniversary of his death: 18941984)]. Bogoslovskie trudy, 27, 212-219. [in Russian].

2. Guruleva, V. V. (1998) Arhimandrit Antonin kak numizmat [Archimandrite Antoninus as the numismatist]. Numizmaticheskij sbornik, 235. [in Russian].

3. Harbuz, B. B. (1996) Numizmatychna kolektsiia Natsionalnoho muzeiu istorii Ukrainy [The numismatic collection of the National museum of history of Ukraine] Visnyk NBU, 3, 84-90. [in Ukrainian].

4. Krainii, K. (2001) Kyivske Tserkovno-istorychne ta arkheolohichne tovarystvo 1872-1920 [Kyiv Church-Historical and Archaeological Society]. Lavrskyi almanakh, 4, 5-64. [in Ukrainian]. 
5. Markov, A. K. (1898) (Comp.). Spisok starinnyh zolotyh i serebrjanyh monet i medalej, prinadlezhashhih Kievo-Pecherskoj lavre [List of ancient gold and silver coins and medals belonging to the Kiev-Pechersk Lavra]. Kiev: Tipografija Kievo-Pecherskoj lavry. [in Russian].

6. Nestulia, O. O. (1995) (Ed.) Dolia tserkovnoi starovyny v Ukraini. 1917-1941 rr. [The fate of the church antiquity in Ukraine in 1917-1941] (Vol. 1). Kyiv: In-t istorii Ukrainy NANU. [in Ukrainian].

7. Petrov, N. I. (1887) O bronzovoj medali s grecheskoj nadpis'ju, najdennoj v 1885 g. $v \mathrm{~m}$. Korsuni, Kievskoj gubernii [About the bronze medal with the Greek inscription, found in 1885 in the municipality of Korsun, Kiev province]. TKDA, 2, 298-312. [in Russian].

8. Petrov, N. I. (1895) Kollekcija drevnih predmetov i monet, pozhertvovannye Cerkovnoarheologicheskomu muzeju pri Kievskoj duhovnoj akademii Pochetnym chlenom Cerkovnoarheologicheskogo Obshhestva pri sej Akademii, dejstvitel'nym statskim sovetnikom Nikolaem Ivanovichem Leopardovym [A collection of ancient objects and coins donated to the Church and Archaeological Museum at the Kiev Theological Academy Honorary Member of the ChurchArchaeological Society at this Academy, the actual State Councilor Nikolai Ivanovich Leopardov]. Kiev, 45-82. [in Russian].

9. Petrov, N. I. (1897) Ukazatel' Cerkovno-arheologicheskogo muzeja pri Kievskoj duhovnoj akademii [Index of the Church-Archaeological Museum at the Kiev Theological Academy]. Kiev, 171-291. [in Russian].

10.Petrov, N. I. (1899) Arheologicheskaja nahodka na horah velikoj cerkvi Kievo-Pecherskoj lavry [Archaeological find on the choirs of the great church of the Kiev-Pechersk Lavra]. TKDA, 6, 176-195. [in Russian].

11.Petrov, N. I. (1997) Vospominanija starogo arheologa [Memories of the old archaeologist]. Proseminarij: Medievistika. Istorija Cerkvi, nauki ta kul'turi, 1, 93-134. [in Russian].

12.Petrov, N. I. Drevnejshih izobrazhenijah svjatogo ravnoapostol'nogo knjazja Vladimira [The most ancient images of the Holy Equal-to-the-Apostles Prince Vladimir]. TKDA, 5, 64-79. [in Russian].

13.Poljushko, G. V. (1898) Vtracheni skarbi Lavrs'kogo muzeju [The lost treasures of the Lavra museum]. Kiev: Abris. [in Russian].

14.Sharipova, L. V. (1993) Z istorii rukopysnoho zibrannia Tserkovno-arkheolohichnoho muzeiu pry Kyivskii dukhovnii akademii [From the history of the handwritten collection of the Church Archaeological Museum at the Kyiv Theological Academy]. Rukopysna ta knyzhkova spadshchyna Ukrainy, 1, 123-133. [in Ukrainian].

15.Shults, I. V. (1993) Do istorii formuvannia kolektsii zhyvopysu Kyievo-Pecherskoho zapovidnyka [The history of the formation of the collection of paintings of the Kiev-Pechersk Reservation] Mystetska spadshchyna. Materialy ta doslidzhennia, 3-15. [in Ukrainian].

16.Zaremba, S. Z. (1995) Ukrainske pamiatkoznavstvo: istoriia, teoriia, suchasnist [Ukrainian Memory Studies: History, Theory, Contemporary]. Tsentr pamiatkoznavstva NAN Ukrainy, Ukrainske tovarystvo okhorony pamiatok istorii ta kultury, 102-117 [in Ukrainian]. 